The International Journal Of Engineering And Science (IJES)

|| Volume || 5 || Issue || 11 || Pages || PP $74-79$ || 2016 ||

ISSN (e): $2319-1813$ ISSN (p): $2319-1805$

THE IJES

\title{
Different Approach in Teaching and Learning in Science for Mongolian Secondary Schools
}

\author{
Huzeyfe CANBAZ \\ Assistant Principal of Darkhan Empathy school, Darkhan-Uul
}

Date of Submission: 07 November $2016 \longrightarrow$

\section{INTRODUCTION}

Constructivist approaches of learning in science suggest that learners can only make sense of new situations in terms of their existing understandings. Previous information is used by learners to interpret observations; meaning is constructed by individuals in a process of adding to or modifying their existing opinions (Driver, 1983; Osborne and Freyberg, 1985; Scott, 1987). The effects of such a view are that teachers need to find out the learners' opinions in order to take these into account in their teaching. Teachers then need to ensure experiences which difficult the learners' current understanding in order to help them restructure their opinions. One sample of a teaching and learning sequence which defines this kind of way is shown in Appendix 1 (Driver and Oldham, 1986).

Constructivist angles have had a important effect on recent research in science education in the UK and elsewhere. Much recent research has been concerned with finding out the opinions which learners typically hold in order to inform teaching. Many science teacher educators are persuaded of the value of a constructivist viewpoint and actively promote a constructivist philosophy. As a result it is now commonplace to find that teachers have been exposed to constructivist opinions, have a commitment to constructivist rules and have made some attempt to modify their practice to take these rules into account. Recently curriculum materials have begun to emerge which adopt an explicit constructivist way, Nuffield Primary Science (1993a) being a prominent sample. Bentley and Watts (1991) claim that there is a difference between what they characterise as the "strong" theoretical version of what is involved in constructivism and the "weak" version of constructivism in practice which many teachers implement in their classrooms. It may be that teachers have misunderstood what the researchers are saying and that any modification to their practice is based on a misinterpretation of constructivist rules.Alternatively the difference claimed by Bentley and Watts may be evidence of a more important problem. Our belief is that the model of constructivism generally put forward is one which is based largely on methods which work for researchers rather than methods which work for teachers in typical classrooms. The discrepancy between the version put forward by researchers and the version applied in the classroom may therefore be indicative of a realistic response by teachers, who may be committed to a constructivist way in principle but have to find ways of making this manageable in practice. We believe that a number of important problems about how to make constructivism applicable to classrooms have not yet been addressed by the various research groups.

\section{Problems appertain to constructivist ways to teaching and learning}

One problem is that of the separation of the phases of the constructivist teaching and learning sequence. Although it is recognised that the elicitation phase may provoke learners to reconsider their thinking (Needham, 1987), the phases are generally described as separate and distinct (Driver and Oldham 1986; Needham, 1987; Scott, 1987). Teachers commonly perceive these phases as separate, and Nuffield Primary Science (1993b) proposes that teachers may have difficulty in switching from one phase to the other. Curriculum materials produced by Leeds (1992) describe how teachers will find it easier to plan activities after the learner's opinions have been identified. However as a model for teaching this separation is not helpful. The practicalities of timing and planning for teaching make this model, which works well as part of a research programme, very difficult to implement. The separation of the two phases also means that the goal of the elicitation phase is only evident to the teacher and not to the learner.

Precisely how the learner's opinions can be taken into account in planning convenient restructuring activities is also a cause for concern. In principle the suggestion that teachers should plan activities on the basis of what the learner already knows and understands seems like an obvious way to proceed. The problem comes with the sheer practicality of attempting to do that with a class of 30 or even 40 or more students. Even if the teacher has adequate information about the learners' initial opinions, attempting to respond to their individual 
opinions can become an impossible exercise in classroom management. We know many teachers and student teachers who have made a commitment to a constructivist way but feel guilty because they are unable to manage to implement this in their practice. Guidance is readily available on the opinions which learners hold and on the range of methods which researchers have used to elicit the learners' opinions (Driver et al, 1985; White and Gunstone, 1992; Driver et al, 1994). However the guidance available to teachers on how to promote restructuring of the learners' opinions is much more limited. Claxton (1986) described the "mountain of samples of children's alternative conceptions" (p126) which were available at that time and noted that the guidance for teachers on how to restructure the learners' opinions was less prominent in the literature. The balance in more recent research remains weighted towards elicitation rather than restructuring, and the comments made by Claxton have been reiterated by Trumper (1990), White (1994) and Prideaux (1995). Research into the opinions that learners hold is relatively "safe" research, in that it is located within a well-documented paradigm, it is easy to manage, and it is very difficult to difficult since it makes no attempt to predict or to prescribe what practice will be effective. By contrast research into how to restructure the learners' opinions has few advantages, even though it may be more valuable for teachers.

Underpinning these concerns is the problem of the relevance of the research to teachers. There seems to be little doubt that researchers frequently are concerned about the classroom relevance of their research. For sample, Driver and Oldham (1986) make it clear that the aim of the Children's Learning in Science Project is to "devise, implement and evaluate teaching materials and tactics which attempt to promote conceptual change" (p108), and the Nuffield Primary Science (1993a) materials are a direct outcome of the SPACE Research Project. In both of these major UK projects teachers have had a central role in researching, developing and trialling teaching materials. However Webb (1990) notes the difficulty for teachers working within a research group to question the values, paradigms and frameworks to which that group is committed and points out the danger of teachers being channelled into certain ways of interpreting their world in forms of research which specifically set out to "emancipate" them (p26).

Thus the interest of teachers in research projects is no guarantee that the outcomes of the research will be viewed as relevant by teachers outside the research groups. There is no doubt that research into the alternative conceptions held by learners is valuable, but it is unfortunate that much of the research does not take the next step of putting forward specific tactics for developing their opinions. This may help to explain why many teachers have made only limited use of the research data. From an action research perspective (Elliot 1991) it appears that the the priority for much of the research has been to improve understanding of the situation in which practice occurs rather than to improve practice directly (Carr and Kemmis, 1986).

\section{Concept cartoons as a way to teaching and learning in science}

It was in response to problems such as these that we developed our cartoon-style drawings as a means of presenting alternative conceptions in science. On the first occasion that they were used we were looking for alternative ways to engage a group of students in thinking about science concepts. We hoped that by presenting alternative opinions in a visually accessible and appealing format we would be able to elicit the students' opinions and ensure convenient challenges which might lead to their opinions being developed further. Typical samples of the concept cartoons which were generated are shown in Figures 1 and 2 (Keogh and Naylor, 1996). A positive response from the students concerned led to the decision to research the use of these concept cartoons systematically. The concept cartoons appeared to ensure an innovative and effective way to teaching and learning in science, with considerable potential value for teachers. They also appeared to address some of the problems mentioned above, raising the possibility of offering an way to teaching and learning in science which took account of the central rules of constructivist angles and which was firmly based on typical classroom practice. Research literature provided a ready source of possible alternative viewpoints which could be presented in a cartoon-style format. Driver et al (1985), SPACE Research Reports (1990-2) and Driver et al (1994) were particularly useful as sources of alternative conceptions. Other sources of inspiration were our own teaching experience, suggestions from colleagues and everyday life experience.

There are some limited references to cartoons and annotated drawings in the science education literature. They have been used for eliciting the learner's opinions (White and Gunstone, 1992; Hayes et al, 1994), for illustrating scientific opinions (Gonick and Huffman, 1990) and as a stimulus to reflection on attitudes in science (Lock, 1991). However the wayes described in the literature do not attempt to explore the use of cartoon-style drawings as a teaching and learning way in science in a systematic way.

In contrast to much educational research, which is sometimes criticised on the grounds that it is frequently of little practical benefit to teachers (Hopkins, 1987; Day, 1995; Hargreaves, 1996), we believed that the concept cartoons could have a direct and immediate effect in the classroom. They also seemed to promote a goalful way to practical work - a "hands-on, minds-on" way (Lorsbach and Tobin, 1992) - rather than the more mechanical way to practical work which is sometimes adopted (Woolnough and Allsop, 1985; Hodson, 1990). 


\section{RESEARCH METHODOLOGY}

An assessment of the use of concept cartoons was carried out by teachers and researchers working in a variety of educational settings. These included school teachers covering the 5-18 age range, college lecturers, teachers working with children with special educational needs, teachers of English as a second language and inservice providers. These teacher-researchers were invited to use the cartoons and to evaluate them critically. Data was collected by a combination of participant and non-participant observation, tape recordings, questionnaires completed by the researchers, oral and written feedback from the learners involved, interviews with some of the researchers and interviews with some of the learners. The groups observed have included primary and secondary students, higher education students, parents and teachers. In many cases authentication of the data was possible using a combination of investigator and methodological triangulation (Denzin 1970).

Action research with our own teaching groups allowed us to discuss alternative formats for the concept cartoons with students and teachers as well as providing further assessment data. This led to a number of developments in the format of the concept cartoons. These include a shift from negatively-worded to positively-worded statements, a shift from statements to questions and a shift from single alternatives to multiple alternatives.

The concept cartoons have also been presented to a variety of audiences at local, regional, national and international Conferences. This has been helpful in gauging the views of a larger cross-section of the teaching population, since our main sample of about 80 teacher-researchers consisted of volunteers who were interested in using the concept cartoons.

\section{EVALUATING THE USE OF THE CONCEPT CARTOONS}

\section{Elicitation}

The concept cartoons were intended to stimulate discussion and to make the learners' opinions explicit through this discussion. The data consistently indicated that the concept cartoons were very effective in this elicitation process. Many teachers commented on how the concept cartoons readily gave them access to the learners' opinions and revealed the learners' conceptual development - "the opinions are so explicit they do not require further probing" was one teacher's comment. One instance of this was an eight-year old child's description of why snow is bright - "Sun pings onto snow, then pings off again into your eyes". A teacher working with children with behavioral difficulties noted that "the children were less inhibited than when asked questions verbally" and other teachers commented on how the concept cartoons were particularly useful for encouraging discussion amongst students who are reluctant to reveal their own thinking.

\section{Restructuring}

Many of the teachers involved observed samples of restructuring in a range of teaching situations. Teachers commented on how the concept cartoons promoted cognitive development in the learners. Learners mentioned sometimes changing their minds when they discussed the concept cartoons - how they "had thought one thing but now believed something else". The concept cartoons appeared to ensure a stimulus which frequently led to the learner's opinions being modified and developed.

\section{Linking together elicitation and restructuring}

There is evidence that the concept cartoons have drawn together the elicitation and restructuring phases of the constructivist teaching sequence. Several clear samples were observed where opinions were being expressed and then modified during the discussions and investigations which emerged from the use of the concept cartoons. In each instance the concept cartoon was the starting point for the discussion and in many no further input to stimulate change in opinions was made by the teacher. One group of 13-14 year olds quickly agreed that there would be no light if clouds covered the sun and then modified their opinions through discussion within the group - "the sun goes behind the clouds so it goes duller not dark" and "the sun is powerful so the light goes through the clouds". Learners were frequently able to make explicit the process which they had gone through in developing their opinions. One student wrote about how the concept cartoons "really made me change my mind" after discussing some concept cartoons with fellow students.

\section{Promoting investigation}

Several samples were quoted of the concept cartoons acting as a stimulus for investigation. One situation was described where "within 10 minutes the whole group were engaged in active investigations". Another teacher remarked on how the concept cartoons led to students testing out their opinions with "no further prompting". Students noted that "you can see what the problem is" and talked about being "unable to wait" to investigate their opinions. Although there were rare instances where the individual or group involved seemed reluctant to engage in investigation, a ready progression from discussion to investigation was the usual response. 


\section{Motivation and interest}

Without exception teachers using the concept cartoons commented on the high levels of interest of the learners. This was evident across the whole range of teaching situations observed. It was particularly notable that the concept cartoons hearten interest amongst students who are normally reluctant to get involved in discussion, enabling students who do not normally converse much about science to articulate their opinions more readily. The level of motivation in each situation evaluated was described as high. Teachers remarked on the speed and ease with which discussions started. The success of the concept cartoons in enthusing students with low levels of motivation was noted by both students and teachers - "There are lots of naughty children in our class but we are busy and better behaved ... . even Dennis, the naughtiest boy in our class, wanted to stay in at the end of the lesson to carry on with the cartoons" was the comment from some 14 year old students in an inner city school. The visual effect of the concept cartoons was emphasized by one pupil's comment that "it beats written work any day!"

\section{Transferability}

The initial decisions about the value of this way in our own teaching have been replicated with a variety of groups in many different teaching situations. These include primary and secondary schools, students with special educational needs, students learning English as a second language, undergraduate and postgraduate students, primary and secondary school teachers and parents. Although the clarity of some of the concept cartoons has had to be improved, teachers generally found them remarkably easy to use and effective in their outcomes. "You just photocopy and go!" was how one teacher described the process.

\section{Other outcomes}

Other outcomes have emerged from the research to extend the potential value for the concept cartoons. Differentiation was one important problem. Although an attempt had been made to produce material which was accessible at a range of levels, we had not anticipated enabling such a wide degree of access as was shown with many of the cartoons. In some instances (Figure 4) the same concept cartoon generated considerable interest in groups ranging from young children to adults holding degrees in physics! One teacher also noted how it was possible to demonstrate progression of opinions within her class through the students' responses to the concept cartoons.

\section{DISCUSSION}

The use of concept cartoons as a means of enabling restructuring of opinions to occur seems particularly important. As noted earlier, guidance on how to restructure the learners' opinions is less well documented than the opinions that they hold and how to elicit them. Concept cartoons which demonstrate alternative viewpoints appear to ensure an important extension to the range of tactics currently available to teachers. They appear to offer a valuable strategy in a variety of teaching situations and with students covering a wide range of ages and capabilities. Another important point is the way that the concept cartoons frequently enabled the elicitation and restructuring phases of the constructivist teaching sequence to go on concurrently or consecutively without the need for teacher intervention. Bentley and Watts (1991) recognise that the linearity of the sequence form elicitation to restructuring is problematic. The use of the concept cartoons provides one means by which the time interval between these two phases may be reduced, enabling the elicitation and restructuring phases to be part of a more continuous process. From the learner's perspective this is probably a more valuable way than one in which elicitation is separated temporally and procedurally from restructuring.

The concept cartoons enabled learners to become more aware of their own opinions and of possible alternative viewpoints so that the need for further investigation became evident to them. Deciding what kind of investigation would be most appropriate therefore became a matter of judgment for the learner rather than for the teacher. In this way the concept cartoons helped to minimize the problem of teachers having to respond to learners individually in the light of their opinions. The goal of elicitation was to help map out the context for an investigation rather than simply to ensure teachers with information about the learner's current level of understanding. Elicitation therefore became a more purposeful part of the process for the learners. The concept cartoons were viewed by many of the teacher-researchers as providing a more realistic perspective on how the constructivist teaching and learning framework might be applied in the classroom.

It is important that development and restructuring of opinions did not always require practical activity as a stimulus. Although it is recognized that activity on its own does not guarantee learning (Driver, 1983; Hodson, 1990; Keogh and Naylor, 1993), the belief persists in many teachers that practical activity is necessary for learning in science to take place. The use of the concept cartoons demonstrates an way to learning in science in which practical activity may not always be necessary, providing a useful sample of a context for learning which "engages the intellect . . and fires the imagination" (Millar and Driver, 1987, p56). 
The use of concept cartoons is consistent with the model of generative science teaching put forward by Wittrock (1994), in which he notes the significance of the learner's attention in promoting learning. They appear to ensure a powerful stimulus to learners to focus their attention on constructing meaningful explanations for the situations described in the drawings. In this way they promote the active engagement of the learner, which is a vital part of the learning process (Millar and Driver, 1987; Somekh and Davies, 1991). The element of cognitive conflict built into the concept cartoons provides an important parallel with the more typical use of cartoons for humour (Larson 1989) and appears to have an effect on motivation. The effect of the use of the concept cartoons on the motivation of learners must be one of the most important factors in evaluating their use in the classroom. Woolnough (1994) notes that if students are motivated and if they are given the freedom and the opportunity, they will find ways of learning. If they are not, they will not bother (page 111).

The focus of this research has been on the value of concept cartoons as a teaching and learning way in science. We have been conscious in the research of the need to ensure that teachers have been fully involved, not only in the assessment of the cartoons but also in constructing the assessment criteria. Much of the assessment has been unrestricted, with teachers making their own decisions about how they chose to evaluate the use of the concept cartoons. In every case the extent to which the concept cartoons have had a positive effect in the classroom has been a central feature of the assessment process. One unanticipated outcome of the research has been the effect on our own practice. The use of the concept cartoons with our own teaching groups has hearten us to reflect on our own practice and has led to important developments in our practice and in our understanding of how best to implement a constructivist way in the classroom. Areas where our practice has changed importantly have included the goal of elicitation, the link between elicitation and restructuring and how the learners' opinions can be taken into account.

We recognize that our views about constructivist rules and practice may be based on a misunderstanding of some aspects of the relevant literature. However we have first-hand evidence that our views about the difficulty of putting constructivist opinions into practice are shared by many teachers. If we have misunderstood the effects of the literature then we suspect that many teachers share our misunderstanding, and we would see it as a priority for research groups to attempt to minimize any possible misunderstandings of the effects of their work. It is encouraging Nuffield Primary Science, which is based firmly on the SPACE Research Project, has recognized the importance of the problems that we have raised and has begun to address them in its most recent publication (Nuffield 1996), pointing out the difference between research and teaching. We hope that our research will help to promote further development of constructivist frameworks in the future.

\section{REFERENCES}

[1]. Bentley, D. and Watts, M. (1991) Constructivism in the curriculum. Can we close the gap between the strong theoretical version and the weak version of theory in practice? The Curriculum Journal, 2, 2, 171-182.

[2]. Carr, W. and Kemmis, S. (1986) Becoming critical: knowing through action research. Victoria, Deakin University.

[3]. Claxton, G. (1986) The alternative conceivers' conceptions. Studies in Science Education, 13, 123-130

[4]. Day, C. (1995) Qualitative research, professional development and the role of teacher educators: fitness for goal. British Educational Research Journal, 21, 3, 357-369.

[5]. Denzin, N.K. (1970) The research act in sociology: a theoretical introduction to sociological methods. London, The Butterworth Group.

[6]. Driver, R. (1983). The Pupil as Scientist? Milton Keynes, Open University Press.

[7]. Driver, R., Guesne, E., and Tiberghien, A. (Eds) (1985). Children's Opinions in Science. Milton Keynes, Open University Press.

[8]. Driver, R., and Oldham, V. (1986). A constructivist way to curriculum development. Studies in Science Education, 13, $105-122$.

[9]. Driver, R., Squires, A., Rushworth, P., and Wood-Robinson, V. (1994). Making Sense of Secondary Science. London, Routledge.

[10]. Elliot, J. (1991) Action Research for Educational Change. Milton Keynes, Open University Press.

[11]. Gonick, L., and Huffman, A. (1990). The Cartoon Guide to Physics. New York, Harper Perennial.

[12]. Hargreaves, D. (1996). Teaching as a Research-based Profession: Possibilities and Prospects. Teacher Training Agency Annual Lecture, London.

[13]. Hayes, D., Symington, D., and Martin, M. (1994). Drawing during science activities in the primary school. International Journal of Science Education, 16, 3, 265-277.

[14]. Hodson, D. (1990). A critical look at practical work in school science. School Science Review, 70, $256,33-40$.

[15]. Hopkins, D. (1987) Teacher research as a basis for staff development. in Wideen, M. and Andrews, I. (Eds) Staff development for school improvement ( $\mathrm{pp} 111-128$ ). Lewes, Falmer.

[16]. Keogh, B., and Naylor, S. (1993). Learning in science: another way in. Primary Science Review, 26, 22-23.

[17]. Keogh, B., and Naylor, S. (1996). Scientists and Primary Schools. Sandbach, Millgate House Publishers.

[18]. Larson, G. (1989). The Pre-History of THE FAR SIDE. Kansas City, Andrews and McMeel.

[19]. Leeds (1992). Leeds National Curriculum Science Support Project. Leeds, Leeds City Council and University of Leeds.

[20]. Lock, R. (1991). Creative work in Biology. School Science Review, 72, 260, 39-46.

[21]. Lorsbach, A., and Tobin, K. (1992). Constructivism as a Referent for Science Teaching. NARST Research Matters, 30.

[22]. Millar, R., and Driver, R. (1987). Beyond Processes. Studies in Science Education, 14, 33-62.

[23]. Needham, R. (1987). Teaching Tactics for Developing Understanding in Science. Leeds, Children's Learning in Science Project, University of Leeds.

[24]. Nuffield Primary Science (1993a). Nuffield Primary Science Teachers' Guides (various titles). London, Collins Educational.

[25]. Nuffield Primary Science (1993b). Nuffield Primary Science Teachers' Handbook. London, Collins Educational.

[26]. Nuffield Primary Science(1996). Nuffield Primary Science Coordinators' Handbook. London, Collins Educational.

[27]. Osborne, R., and Freyberg, P. (1985). Learning in Science. Auckland, Heinemann. 
[28]. Prideaux, N. (1995). Different wayes to the teaching of the energy concept. School Science Review, 77, $278,49-57$.

[29]. Scott, P. (1987). A Constructivist View of Teaching and Learning. Leeds, Children's Learning in Science Project, University of Leeds.

[30]. Science Processes and Concept Exploration (SPACE) (1990-2). Research Reports, various titles. Liverpool, Liverpool University Press.

[31]. Somekh, B. and Davies, R. (1991) Towards a pedagogy for information technology. The Curriculum Journal, 2, 2, 153-170.

[32]. Trumper, R. (1990). Being constructive: an alternative way to the teaching of the energy concept. International Journal of Science Education, 12 , 4, 343-354

[33]. Webb, R. (1990) The origins and aspirations of practitioner research. in Webb, R. (Ed), Practitioner research in the primary school (pp12-33). London, Falmer.

[34]. White, R. (1994). Dimensions of content. in Fensham, P., Gunstone, R., and White, R. (Eds.), The Content of Science (pp255-262). London, Falmer.

[35]. White, R., and Gunstone, R. (1992). Probing Understanding. London, Falmer.

[36]. Wittrock, M. (1994). Generative Science Teaching. in Fensham, P., Gunstone, R., and White, R. (Eds.), The Content of Science (pp29-38). London, Falmer .

[37]. Woolnough, B. (1994). Effective Science Teaching. Milton Keynes, Open University Press.

[38]. Woolnough, B., and Allsop, T. (1985). Practical Work in Science. Cambridge, Cambridge University Press. 